\title{
Cell viability in SH-SY5Y neuroblastoma cells in folic acid application by using JACK-STAT pathway
}

\author{
Şefik Güran ${ }^{1}$, Zehra Zeynep Kaplan ${ }^{2}$, Yiğit Cemo Kılıç ${ }^{2}$, Zehra Dilşad Çoban ${ }^{3}$, Yunus Emre Polat ${ }^{2}$, Kardelen \\ Güleç ${ }^{2}$, Alpertunga Yüce ${ }^{2}$, Vildan Tunçbilek ${ }^{2}$, Meral Zehra Baykara ${ }^{2}$, Özgür Kılıçarslan ${ }^{1}$ \\ (1) University of Health Sciences Gulhane Medical School, Department of Medical Biology, Ankara, Turkey \\ (2) University of Health Sciences, Gulhane Medical School, Ankara, Turkey \\ (3) National Defense Ministry, Çankaya Pavilion Infirmary, Ankara, Turkey
}

Date submitted:

Apr 16, 2019

Date accepted:

May 21, 2019

Online publication date:

December 15, 2019

\section{Corresponding Author:}

Şefik Güran

University of Health Sciences,

Gulhane Medical School

Department of Medical Biology,

Ankara, Turkey

sefik.guran@sbu.edu.tr

Keywords: Folic acid, neuroblastoma, cell proliferation, cell viability, JAK/STAT pathway.

\section{ABSTRACT}

Aims:Folic acid and folate are forms of a water-soluble B vitamin. Folic acid is used as a supplement by women during pregnancy to reduce the risk of neural tube defects. Folic acid supplementation is reported with the suppression of tumor development in literature. Here, the effect of folic acid was analyzed for cell proliferation and viability on neuroblastoma cells. The gene expression differences of folic acid receptors and JAK/STAT pathway were analyzed.

Methods:FA solutions were prepared on $1 \mu \mathrm{M}, 5 \mu \mathrm{M}, 10 \mu \mathrm{M}$ concentrations and applied on neuroblastoma SH-SY5Y cells. XTT cell proliferation assay and cell viability assay were used for finding cell proliferation and viability. The gene expression differences was analyzed on FOLR1, JAK1, STAT3, PIAS1, PTPN1 and SOCS-1 genes on neuroblastoma cells by using real time polymerase chain reaction.

Results:In XTT assay, LD50 dosage was found as $22 \mu \mathrm{M}$ FA concentration on SH-SY5Y neuroblastoma cells. Cell viability was found as $93 \%$ in control, $96 \%$ in $1-5 \mu \mathrm{M}, 97 \%$ in $10 \mu \mathrm{M}$ folic acid application $(p<0.005)$. FOLR1, STAT3 and SOCS-1 gene expressions were found higher than control $(p<0.005)$. JAK1, PIAS1 and PTPN1 gene expressions were found as similar to control $(p \geq 0.05)$

Conclusions:Folic acid in different concentrations increased the neuroblastoma tumor cell viability. Our results supported similar findings on the same cell type in literature. Increased FOLR1 gene expression results can be interpreted that FA causes an increasing in folate receptors. High STAT3 and SOCS-1 gene expressions observed in our experiment may be the result of folic acids' effect on JAK/STAT pathway in neuroblastoma cells.

\section{Introduction}

Folic acid (FA) as a vitamin (folate) has various roles in bodily functions. Human body needs FA as a cofactor in DNA synthesis, DNA repair and DNA methylation. FA is especially important in cell division and growth, such as in infancy and pregnancy $(1,2)$. FA is used as a supplement by women during pregnancy to reduce the risk of neural tube defects in the baby $(3,4)$. Folate receptors (FR) are high affinity receptors that transport folate via endocytosis. FR1/FRa (adult form), FR2/FR $\beta$ (fetal form) and FR3/FRy are activated by folic acid in a cell. FR1, FR2 and FR3 proteins are encoded by FOLR1, FOLR2 and FOLR3 genes respectively (5). In literature, FA uses was reported with the suppression role of tumor development. Kuo et al. pointed out that FA inhibits colon cancer cell proliferation using FRa-SRC/ ERK1/2/NFKB/TP53 pathway (6). Hansen et al. presented that FA activates STAT3 through FRa in a Janus Kinase (JAK)-dependent manner in FRa-positive HeLa cells (7). In JAK-STAT pathway, "the signal transducer and activator of transcription 3-STAT3" is a well-described pro-oncogene found constitutively activated in several cancer types. Three major groups of proteins that cells use to regulate this signaling pathway are "protein inhibitors of activated STAT-PIAS", "protein tyrosine phosphatases-PTPs and "suppressors of cytokine signaling-SOCS" (8-10). PIAS, PTP and SOCS are the protein families which can be affected by JAK/STAT pathway. In this study, only one gene in each protein family group was selected (PIAS1, PTPN1 and SOCS-1 genes for PIAS1, PTPN1 and SOCS1 proteins respectively) (11-13).

Neuroblastoma cell lines are transformed, neural crest derived cells, capable of unlimited proliferation in vitro (14). $\mathrm{SH}$ SY5Y human neuroblastoma cells express FR1 protein. So these cells are suitable for folate studies $(15,16)$. Folate receptors bind folate and mediates delivery of tetrahydrofolate to the interior of cells. Tetrahydrafolate molecules regulate many folate-dependent processes in a cell (17).

The measurement of cell proliferation/viability plays an essential role in all forms of cell culture. Cell proliferation/viability can be used to correlate cell behavior to cell number. XTT/MTT assays are used for finding the cell proliferation ratios. For cell viability, trypan blue assay is the most common form $(18,19)$. Gene expression is the process by which genetic instructions 
are used to synthesize gene products. These products are usually proteins, which go on to perform essential functions as enzymes, hormones and receptors (20).

We aimed to analyze the possible role of FA on cell proliferation and viability in SH-SY5Y neuroblastoma cell lines by using XTT and trypan blue assays. Gene expression alterations of folate receptor gene (FOLR1) were analyzed. JAK, STAT3, PIAS1, PTPN1 and SOCS-1 genes were studied in JAK/STAT pathway. First total RNA isolation was performed on each culture flask. Than c-DNAs of selected gene was obtained. Real-time polymerase chain reaction (RT-PCR) was performed for finding gene expression differences by using c-DNAs as a template.

\section{Methods}

This study is designed due to Ethical Board Decision of Gulhane Military Medical Academy-2013-4.

\section{Preparation of FA Solutions}

FA was obtained from I.E.Ulagay AS Company. FA was diluted in physiologic serum in $1 \mu \mathrm{M}, 5 \mu \mathrm{M}, 10 \mu \mathrm{M}$ concentrations $(19,21)$.

\section{Cell Culture}

Adult neuroblastoma cell line SH-SY5Y (ATCC CRL-226612) were cultured and incubated in RPMI-1640 (Sigma-Aldrich-R8758) including 10\% (v/v) FBS (BiochromAG, Germany) and $1 \%(\mathrm{v} / \mathrm{v})$ gentamycin (Biological Industries, Israel) at $37^{\circ} \mathrm{C}$ in $5 \% \mathrm{CO}_{2}$ Heraus incubator (Hanau, Germany). We arranged four cell culture groups; one for control, three for FA solutions $(1 \mu \mathrm{M}, 5 \mu \mathrm{M}, 10 \mu \mathrm{M}$ concentrations).

\section{XTT Cell Proliferation Assay}

The cytotoxic effects of FA solutions were analyzed by using the protocol of XTT (2,3-bis(2-methoxy-4-nitro-5-sulfophenyl)5-[(phenylamino)carbonyl)]-2H-tetrazolium hydroxide) assay kit on mouse MSCs. "XTT assay" kit (Trevigen XTT Cell proliferation assay kit-Cat No: 4891-025-K) was used in accordance with manufacturer's instructions. The results were obtained by using "ELISA reader" (22). LD-50 dosages were found as $22 \mu \mathrm{M}$ FA concentration. We prepared the FA solution's concentrations below the toxic dosage $(1 \mu \mathrm{M}, 5 \mu \mathrm{M}, 10 \mu \mathrm{M}$ FA concentrations)

\section{Cell viability assay}

Trypan blue (Sigma Aldrich Co. 302643) as a stain was used in procedures for viable cell counting. Trypan blue was diluted at $0.8 \mu \mathrm{M}$ in PBS. It was mixed with the cells $1: 1$. In this method, live (viable) and dead (non-viable) cells were counted on hemocytometer.

\section{RNA Isolation and cDNA Synthesis}

Cells were harvested by using trypsin/EDTA solution (Sigma Aldrich/ T4049) 24 hours after Zn application. RNA isolation was performed three times in each culture flasks. The c-DNAs were obtained in each condition. The c-DNAs were run on $2 \%$ agarose gel for control.

\section{Real-time Polimerase Chain Reaction (RT-PCR)}

The expression patterns of selected genes [FOLR1 (OMIM: 136430), JAK1 (OMIM: 147795), STAT3 (OMIM: 102582), PIAS1 (OMIM: 603566), PTPN1 (OMIM: 176885) and SOCS-1 (OMIM: 603597)] were found in RT-PCR analyses. Beta Actin-ACTB (OMIM: 102630) gene was used as an internal con- trol in each reaction. All the forward and reverse primers were designed from Primer Bank (https://pga.mgh.harvard.edu/primerbank/). Each RT-PCR reaction was performed in $20 \mu \mathrm{l}[10 \mu \mathrm{l}$ $2 \times$ SYBR (Applied Biosystems), $5 \mu$ c DNA, $1 \mu$ l primer, $3 \mu l d$ $\mathrm{H} 2 \mathrm{O}]$ in reaction tubes in Roche Applied Science: LightCycler ( 480 System. For optimum results, RT-PCR reactions were performed six times for each gene in each condition. The gene expression levels were found in FOLR1, JAK1, STAT3, PIAS1, PTPN1 and SOCS-1 genes in control and FA treated groups. FA treated group results were compared with control group results. Mean values were obtained in all groups.

\section{Statistical analyses}

The mean values of RT-PCR results were obtained by dividing from each of RT-PCR reaction result. Student's t test (one sample t test) was used for two-group comparisons by using MS Exell. Student $t$ tests results ( $p$ values) represent two group comparisons among the control and the FA treated groups (Table 1 and Figure 1).

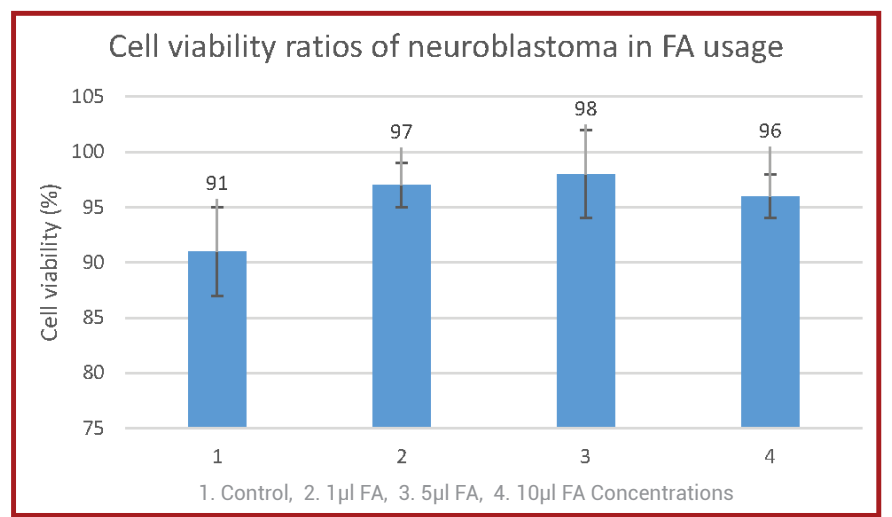

Figure 1. Cell viability ratios on neuroblastoma cells in FA application. All the cell viability ratios were statistically significant $(p \leq 0.05)$.

\section{Results}

In XTT assay, LD50 dosage was found as $22 \mu \mathrm{M}$ FA concentration on SH-SY5Y neuroblastoma cells. Due to this result, FA dosages were chosen lower than LD50 dosage in our study $(1 \mu \mathrm{M}, 5 \mu \mathrm{M}, 10 \mu \mathrm{M}$ concentrations). Cell viability assay results were $93 \pm 4 \%$ viable in control, $96 \pm 2 \%$ viable in $1 \mu \mathrm{M}$ FA application, $96 \pm 4 \%$ viable in $5 \mu \mathrm{M}$ FA application, $97 \pm 2 \%$ viable in $10 \mu \mathrm{M}$ FA application. So, FA in different concentrations changed the neuroblastoma tumor cell viability. The results were found as statistically significant $(p<0.005)$ (Figure 1).

In RT-PCR analysis in control group (untreated with FA), FOLR1 gene expression level was found to be $1.09 \pm 0.4$ in average. FOLR1 gene expression levels were found as 2.28 \pm 0.1 , $2.40 \pm 0.1$ and $1.90 \pm 0.4$ in treated $1 \mu \mathrm{M}, 5 \mu \mathrm{M}, 10 \mu \mathrm{M}$ FA concentrations respectively. These values obtained in FA treated groups were found to be statistically significant when compared with the control group ( $p \leq 0.05$ ) (Table 1). In control group, JAK1 and STAT3 gene expression levels were found to be $3.04 \pm 0.5$ and $0.22 \pm 0.4$ respectively. At $1 \mu \mathrm{M}, 5 \mu \mathrm{M}$, and $10 \mu \mathrm{M}$ concentrations, JAK1 gene expressions were analyzed as $3.14 \pm 0.6$ and $3.22 \pm 0.1$ and $3.09 \pm 0.7$ respectively. These values were statistically insignificant when compared to the control group $(p \geq 0.05)$ (Table 1). At $1 \mu \mathrm{M}, 5 \mu \mathrm{M}$, and $10 \mu \mathrm{M}$ concentrations, STAT3 gene expressions were analyzed as $1.22 \pm 0.4$ and $1.09 \pm 0.4$ and $1.13 \pm 0.4$ respectively. These values were statistically significant when compared to the control group $(p<0.05)$ (Table 1). Results can be interpreted that FA causes an increasing in fo- 


\begin{tabular}{|c|c|c|c|c|c|c|c|}
\hline \multirow[b]{2}{*}{ GENES } & \multicolumn{7}{|c|}{ Gene Expression Levels } \\
\hline & $\begin{array}{l}\text { Control } \\
\text { Group }\end{array}$ & $1 \mu \mathrm{M}$ FA solution & $P$ value & $\begin{array}{c}5 \mu \mathrm{M} F A \\
\text { solution }\end{array}$ & $P$ value & $10 \mu \mathrm{M}$ FA solution & $P$ value \\
\hline FOLR1 & $1.09 \pm 0.4$ & $2.28 \pm 0.1$ & $p<0.005$ & $2.40 \pm 0.1$ & $p<0.005$ & $1.90 \pm 0.4$ & $p<0.005$ \\
\hline JAK1 & $3.04 \pm 0.5$ & $3.14 \pm 0.6$ & $p \geq 0.05$ & $3.22 \pm 0.1$ & $p \geq 0.05$ & $3.09 \pm 0.7$ & $p \geq 0.05$ \\
\hline STAT3 & $0.22 \pm 0.4$ & $1.22 \pm 0.4$ & $p<0.005$ & $1.09 \pm 0.4$ & $p<0.005$ & $1.13 \pm 0.4$ & $p<0.005$ \\
\hline PIAS1 & $2.19 \pm 0.5$ & $2.22 \pm 0.5$ & $p \geq 0.05$ & Not obtained & - & $2.19 \pm 0.5$ & $p \geq 0.05$ \\
\hline PTPN1 & $4.09 \pm 0.4$ & $4.09 \pm 0.6$ & $p \geq 0.05$ & $4.08 \pm 0.1$ & $p \geq 0.05$ & $4.10 \pm 0.5$ & $p \geq 0.05$ \\
\hline SOCS-1 & $0.99 \pm 0.1$ & $1.53 \pm 0.6$ & $p<0.005$ & Not obtained & - & $1.67 \pm 0.1$ & $p<0.005$ \\
\hline
\end{tabular}

late receptors and JAK/STAT pathway.

PIAS1, PTPN1 and SOCS-1 gene expressions were studied in FA free condition as control. Control results were found in PIAS1 gene as $2.19 \pm 0.5$, in PTPN1 gene as $4.09 \pm 0.4$ and in SOCS-1 gene as $0.99 \pm 0.1$ in these analyses (Table 1). In PIAS1 gene, gene expression results were found as $2.22 \pm 0.5$ and $2.19 \pm 0.5$ in $1 \mu \mathrm{M}$ and $10 \mu \mathrm{M}$ FA solutions. In PTPN1 gene, gene expression results were found as $4.09 \pm 0.6$ and $4.08 \pm 0.1$ and $4.10 \pm 0.5$ in $1 \mu \mathrm{M}, 5 \mu \mathrm{M}$ and $10 \mu \mathrm{M}$ FA solutions respectively. These results obtained in PIAS1 and PTPN1 genes were found as statistically insignificant due to control results $(p \geq 0.05)$. In SOCS-1 gene, gene expression results were found as $1.53 \pm 0.6$ and $1.67 \pm 0.1$ in $1 \mu \mathrm{M}$, and $10 \mu \mathrm{M}$ FA solutions. The results obtained in SOCS-1 gene were found as statistically significant due to control results $(p<0.05)$ (Table 1, Figure 2).

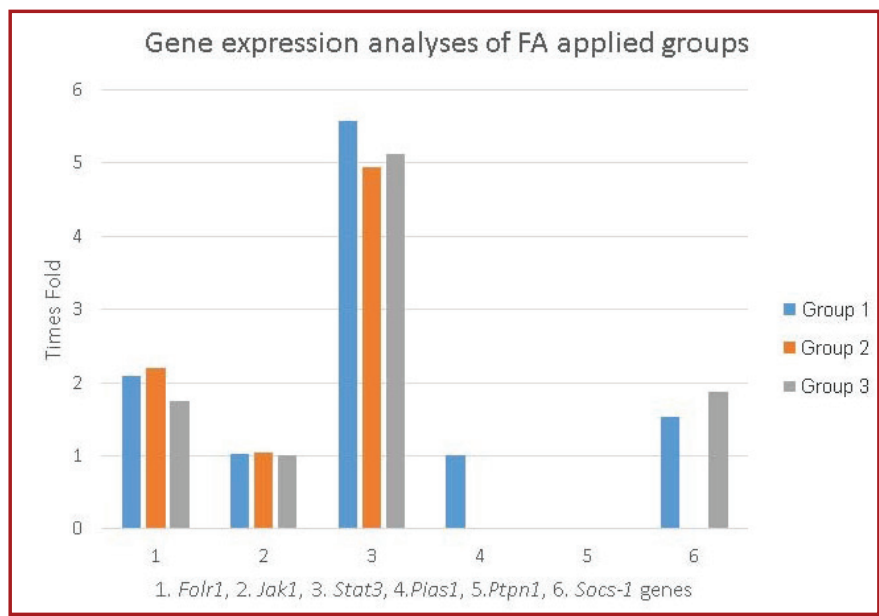

Figure 2. The graph represents gene expression results of FA applied groups. Group 11 indicates $1 \mu \mathrm{M}$, group 2 indicates $5 \mu \mathrm{M}$, and group

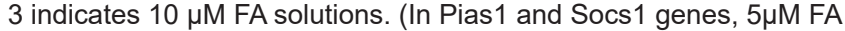
studies were not obtained. In Pias1 $10 \mu \mathrm{M}$ FA application and in Ptpn1 gene $1 \mu \mathrm{M}, 5 \mu \mathrm{M}, 10 \mu \mathrm{M}$ FA applications, no difference in gene expressions were found)

\section{Discussion}

Reduced derivatives of FA play a critical role in the development, function and repair of the central nervous system. However, the molecular systems regulating folate uptake and homeostasis in the central nervous system remain incompletely defined $(23,24)$. On the other hand, FA supplementation and cancer relationship is still a debate. Mortansen et al. explained that FA supplementation was not associated with risk of major childhood cancers (25). In the population consisting of heavy smokers, high folate levels had been reported with an additive effect to the cancerogenic role of smoking (26). Hatami et al. explained that high intakes of folate were associated with reduced odds of breast cancer (27). Despite of these findings, the literature is not clear about neuroblastoma tumors. French et al. found that FA fortification was associated with a $60 \%$ reduction in neuroblastoma. The authors pointed out that further investigation was needed into the role of folate metabolism in the formation and prevention of neuroblastoma and other embryonically determined cancers (28). For finding the role of FA on neuroblatoma we performed this study on adult neuroblastoma SH-SY5Y cell line.

Cell-based assays are essentials in toxicity studies for screening the effects of selected molecule on cell viability and cell proliferation. Cell viability and cell proliferation can be analyzed by using XTT/MTT cell proliferation assay and cell viability assay. LD50 is the amount of a material, given all at once, which causes the death of $50 \%$ of a group of test animals or cells (29). Here we performed XTT assay in our study and found LD50 dosages as $22 \mu \mathrm{M}$ FA concentration. FA concentrations, lower than LD50 dosages were chosen in our study. Distinguishing between live and dead cells is very important for investigation of growth control and cell death. There are a lots of cell viability methods use in laboratory (from the most routine and easy trypan blue assay to highly complex types) (22). Cell viability was analyzed by using trypan blue staining in our study. Our results demonstrated that FA stimulated cell viability in certain concentrations (Figure 1). In literature, generally FA stimulates neuronal type cell's viability. Liu et al. reported that folic acid supplementation stimulated neural stem cell proliferation dose-dependently (30). Li et al. explained that high FA concentrations increased the cell viability in SH-SY5Y neuroblastoma cells (18). The similar results obtained in our study, supported the literature findings.

The protein encoded by FOLR1 gene is a member of the FR family. Members of this gene family bind FA, and transport tetrahydrofolate into cells. FOLR1 gene is required for normal embryonic development and normal cell proliferation (31). In our study, FOLR1 gene expressions was found higher than control in all FA treated groups (Table 1 and Figure 2). This finding represents that FA enhances FR production. Similar reports were observed in the literature (31).

JAK1 gene encodes a membrane protein that is a member of a class of protein-tyrosine kinases. The encoded kinase phosphorylates STAT proteins and plays a key role in interferon-alpha/beta and interferon-gamma signal transduction (32). STAT protein is activated through phosphorylation in response to various cytokines and growth factors. This protein mediates the expression of a variety of genes in response to cell stimuli, and 
thus plays a key role in many cellular processes such as cell growth and apoptosis (33). In our study, FA stimulated STAT3 gene expression (Table 1). This result may represent that FA uses JAK/STAT pathway in certain concentration on neuroblastoma cells (34). Hansen et al. reported that FA stimulated the same protein (STAT3) in FR1 positive HeLa cells (7).

JAK-STAT signaling is able to interconnect with other cell-signaling pathways, such as the PI3K/AKT/mTOR pathway (35). JAK-STAT signaling can also integrate with the MAPK/ERK pathway. Grb2 protein which is important for MAPK/ERK signaling, can bind to receptors phosphorylated by JAKs. MAPK/ ERK signaling activates STATs (36). Interleukin-2 (IL-2) receptor signaling in $\mathrm{T}$ cells is another alternative signaling mechanism. IL-2 receptors have y (gamma) chains, which are associated with JAK3, which then phosphorylates key tyrosines on the tail of the receptor. Phosphorylation then recruits an adaptor protein called Shc, which activates the MAPK/ERK pathway, and this facilitates gene regulation by STATs (37). Given the importance of the JAK-STAT signaling pathway, particularly in cytokine signaling, there are a variety of mechanisms that cells possess to regulate the amount of signaling that occurs. Also there are three protein families which are used in cells to regulate this signaling pathway (8-10). In our study, the roles of these protein families (PIAS, PTP and SOCS) in FA uses were analyzed (12-14). We found that SOCS-1 gene which encode SOCS-1 protein (participates in SOCS major protein group) was activated by FA application (Table 1 and Figure 2).

Our results indicate that FA supplementation needs a lot studies for finding the effect of cell behavior and viability in neuroblastoma and other types of tumors.

\section{Acknowledgments}

Study was designed by ZZK, YCK, and ŞG. Data was collected and analyzed by DZC, ZZK, YCK, YEP, KG, AY, VT, MZB, ÖK. Manuscript was written by ŞG. There was no financial assistance with the project.

\section{Conflict of Interest}

The authors declared they do not have anything to disclose regarding conflict of interest with respect to this manuscript.

\section{References}

1. Weinstein SJ, Hartman TJ, Stolzenberg-Solomon R, et al. Null association between prostate cancer and serum folate, vitamin $B(6)$, vitamin $B(12)$, and homocysteine. Cancer Epidemiol Biomarkers Prev. 2003;12(11 Pt 1):1271-1272.

2. Ebisch IM, Thomas CM, Peters WH, Braat DD, Steegers-Theunissen RP. The importance of folate, zinc and antioxidants in the pathogenesis and prevention of subfertility. Hum Reprod Update. 2007;13(2):163-174.

3. Saccone G, Berghella V. Folic acid supplementation in pregnancy to prevent preterm birth: a systematic review and meta-analysis of randomized controlled trials. Eur $\mathrm{J}$ Obstet Gynecol Reprod Biol. 2016;199:76-81.

4. Lintas C. Linking genetics to epigenetics: The role of folate and folate-related pathways in neurodevelopmental disorders. Clin Genet. 2019;95(2):241-252

5. Kelemen LE. The role of folate receptor alpha in cancer development, progression and treatment: cause, consequence or innocent bystander? Int. J. Cancer 2006;119(2):243-250.

6. Kuo CT, Chang C, Lee WS. Folic acid inhibits COLO205 colon cancer cell proliferation through activating the $\mathrm{FRa/C-SRC/ERK1/2/NFKB/TP53} \mathrm{pathway:} \mathrm{in} \mathrm{vitro} \mathrm{and} \mathrm{in}$ vivo studies. Sci Rep. 2015;5:11187.

7. Hansen MF, Greibe E, Skovbjerg S, et al. Folic acid mediates activation of the pro-oncogene STAT3 via the Folate Receptor alpha. Cell Signal. 2015;27(7):1356-1368.

8. Shuai K. Regulation of cytokine signaling pathways by PIAS proteins. Cell Research 2006;16(2):196-202.

9. Hebenstreit D, Horejs-Hoeck J, Duschl A. JAK/STAT-dependent gene regulation by cytokines. Drug News Perspect. 2005:18(4):243-249.

10. Krebs DL, Hilton DJ. SOCS proteins: negative regulators of cytokine signaling. Stem Cells 2001;19(5):378-387.

11. Schmidt D, Müller S. Members of the PIAS family act as SUMO ligases for c-Jun and p53 and repress p53 activity. Proc Natl Acad Sci U S A 2002;99(5):2872-2877.

12. Sangwan V, Paliouras GN, Abella JV, et al. Regulation of the Met receptor-tyrosine kinase by the protein-tyrosine phosphatase 1B and T-cell phosphatase. J Biol Chem. 2008;283(49):34374-34383.

13. Ben-Zvi T, Yayon A, Gertler A, Monsonego-Ornan E. Suppressors of cytokine signaling (SOCS) 1 and SOCS3 interact with and modulate fibroblast growth factor receptor signaling. J Cell Sci. 2006;119(Pt 2):380-387.

14. Shastry P, Basu A, Rajadhyaksha MS. Neuroblastoma cell lines--a versatile in vitro model in neurobiology. Int $\mathrm{J}$ Neurosci. 2001;108(1-2):109-126.

15. Human Protein Atlas. https://www.proteinatlas.org/ENSG00000110195-FOLR1/cell/Accessed April 1, 2019

16. Li W, Jiang M, Xiao Y, Zhang X, Cui S, Huang G. Folic acid inhibits tau phosphorylation .through regulation of PP2A methylation in SH-SY5Y cells. J Nutr Health Aging 2015;19(2):123-129.

17. Guo J, Schlich M, Cryan JF, O'Driscoll CM. Targeted Drug Delivery via Folate Receptors for the Treatment of Brain Cancer: Can the Promise Deliver? J Pharm Sci. 2017;106(12):3413-3420.

18. Avelar-Freitas BA, Almeida VG, Pinto MCX, et al. Trypan blue exclusion assay by flow cytometry. Braz J Med Biol Res. 2014;47(4):307-3015.

19. Güran Ş, Dilşad Çoban Z, Fermanlı O, Aydıngöz E, İpek E. Folic acid and zinc inhibit angiogenesis in chicken chorioallontoic membrane model via angiogenic factor genes. Gulhane Med J. 2018;60(3):67-70.

20. Allenby G, Bocquel MT, Saunders M, et al. Retinoic acid receptors and retinoid $X$ receptors: interactions with endogenous retinoic acids. Proc Natl Acad Sci USA 1993;90(1): 30-34.

21. Oosterbaan AM, Steegers EA, Ursem NT. The effects of homocysteine and folic acid on angiogenesis and VEGF expression during chicken vascular development. Microvasc Res. 2012;83(2):98-104. 
22. Coco-Martin JM, Oberink JW, van der Velden-de Groot TA, Beuvery EC. Viability measurements of hybridoma cells in suspension cultures. Cytotechnology 1992;8(1):57-64.

23. Wollack JB, Makori B, Ahlawat S, et al. Characterization of folate uptake by choroid plexus epithelial cells in a rat primary culture model. J Neurochem. 2008;104(6):14941503.

24. Çoban ZD, Guran S, Sagaltıcı AS. In vitro effects of zinc and folic acid on the expressions of Neurogenin 3, Kruppel-like factor 4, c-Myc, Nanog, Nestin and POU class 5 homeobox 1 genes. J Exp Integr Med. 2015;5(2):75-80.

25. Mortensen JH, Øyen N, Fomina T, et al. Supplemental folic acid in pregnancy and childhood cancer risk. $\mathrm{Br} \mathrm{J}$ Cancer 2016;114(1):71-75.

26. Stanisławska-Sachadyn A, Borzyszkowska J, Krzemiński $M$, et al. Folate/homocysteine metabolism and lung cancer risk among smokers. PLoS One. 2019;14(4):e0214462.

27. Albuquerque RC, Baltar VT, Marchioni DM. Breast cancer and dietary patterns: a systematic review. Nutr Rev. 2014;72(1):1-17.

28. French AE, Grant R, Weitzman S, et al. Folic acid food fortification is associated with a decline in neuroblastoma. Clin Pharmacol Ther. 2003;74(3):288-294.

29. Rispin A, Farrar D, Margosches E, et al. Alternative methods for the median lethal dose $(\operatorname{LD}(50))$ test: the up-and-down procedure for acute oral toxicity. ILAR J. 2002;43(4):233-243.

30. Liu H, Huang G, Zhang X, Ren D, Wilson JX. Folic Acid Supplementation Stimulates Notch Signaling and Cell Proliferation in Embryonic Neural Stem Cells. J Clin Biochem Nutr. 2010;47(2):174-180.

31. Cheung A, Bax HJ, Josephs DH, et al. Targeting folate receptor alpha for cancer treatment. Oncotarget. 2016;7(32):52553-52574.

32. Zhang X, Yang J, Bian Z, Shi D, Cao Z. Long noncoding RNA DANCR promotes nasopharyngeal carcinoma progression by interacting with STAT3, enhancing IL-6/JAK1/STAT3 signaling. Biomed Pharmacother. 2019;113:108713.

33. Frank DA. STAT3 as a central mediator of neoplastic cellular transformation. Cancer Lett. 2007;251(2):199-210.

34. 34. Morris R, Kershaw NJ, Babon JJ. The molecular details of cytokine signaling via the JAK/STAT pathway. Protein Sci. 2018;27(12):1984-2009

35. Jason SR, Kristin MR, Douglas AH. The JAK/STAT signaling pathway. Journal of Cell Science 2004;117(8):12811283.

36. Jain N, Zhang T, Fong SY, Lim CP, Jain XC. Repression of Stat3 activity by activation of mitogen-activated protein kinase (MAPK). Oncogene 1998;17(24):3157-3167.

37. Thomas RM, Iris C. Interleukin-2 Receptor Signaling: At the Interface between Tolerance and Immunity. Immunity 2010;33(2):153-165. 